\title{
Experimental Investigation of the Effects on Rheological and Filtration Properties of Water-Based Drilling Mud of Fly Ash Addition with Different Particle Size and Concentration
}

\author{
Abdullah ÖZKAN ${ }^{1 *}$, Sitkı Ekrem TURAN ${ }^{1} \mathbb{D}$, Vildan ÖZKAN $^{1} \mathbb{B}$ \\ ${ }^{1}$ Iskenderun Technical University, Faculty of Engineering and Natural Science, Department of Petroleum \\ and Natural Gas Engineering, Hatay, TURKEY
}

Geliş / Received: 13/07/2020, Kabul / Accepted: 15/12/2020

\begin{abstract}
Performance of the drilling fluid is a great concern in drilling operations. Recently, many studies have been carried out on how to perform drilling operations more economically and effectively. Herein this paper effect of the fly ash addition with different particle sizes and concentrations on rheological and filtration properties of drilling muds is studied. For this purpose, fly ash is sieved and $32 \mu \mathrm{m}, 63 \mu \mathrm{m}$ and $90 \mu \mathrm{m}$ sub sieve samples are obtained. Each of these predetermined fly ash samples with different particle sizes are mixed with fly ash $1,2,3,4,5 \% \mathrm{w} / \mathrm{v}$. The physical properties of the drilling muds were determined based on API recommended methods including all filtration and rheological properties. It is observed that rheological properties and filtration properties are positively effected by fly ash addition. For rheological properties effect of particle size on related properties are similar while for the filtration properties particle size matters where lost circulation is decreased with smaller particle sizes.
\end{abstract}

Keywords: fly ash, drilling muds, rheological properties, filtration properties

Farklı Boyut ve Konsantrasyonlarda Uçucu Kül İlavesinin Su Bazlı Sondaj Çamurlarının Reolojik ve Filtrasyon Özelliklerine Etkisinin Deneysel Olarak Araştırılması

$\ddot{O} \mathbf{z}$

Sondaj akışkanlarının performansı sondaj operasyonları açısından büyük önem taşımaktadır. Son dönemde, sondaj işlemlerinin daha ekonomik ve etkin bir şekilde nasıl gerçekleştirilebileceği ile ilgili birçok çalışma yapılmaktadır. Bu çalışmada sondaj çamuruna farklı tane boyutunda ve farklı konsantrasyonlarda eklenen uçucu külün sondaj çamurunun reolojik ve filtrasyon özelliklerine etkisi incelenmiştir. Bu amaçla uçucu kül elekten geçirilerek $32 \mu \mathrm{m}, 63 \mu \mathrm{m}$ ve $90 \mu \mathrm{m}$ elek altı örnekleri elde edilmiştir. Elde edilen bu farklı tane boyutlu uçucu kül numuneleri ağırlıkça \% 1,2,3,4,5 konsantrasyonda olacak şekilde sondaj çamuruna eklenmiştir. Hazırlanan çamur sistemlerinin filtrasyon ve reolojik özellikleri API metotlarına uygun şekilde test edilmiştir. Çamurun reolojik ve filtrasyon özelliklerinin uçucu kül eklenmesinden pozitif etkilendiği gözlemlenmiştir. Farklı tane boyutlarının çamurun reolojik özellikleri üzerinde benzer etki gösterirken, tane boyutunun etkisi özellikle küçük tane boyutlu kül eklendiğinde filtrasyon kayıplarının azalması yönünde kendini göstermiştir.

Anahtar Kelimeler: uçucu kül, sondaj çamurları, reolojik özellikler, filtrasyon özellikleri. 


\section{Introduction}

Oil exploration activities have increased as the world's energy demand increase and the tools used in the oil drilling operations becomes more of an issue. The main function of drilling fluid is to provide enough hydrostatic pressure, keeping the borehole clean by removing fragments and drill cuttings, cooling and lubricating drill bit and ensuring stability between formations (Abdo and Haneef, 2012). Therefore, selection of the relevant drilling fluids and the changes of the related properties of the selected fluid according to borehole conditions are some of the major concerns in drilling operations (Matho, 2010; Caenn et al., 2011). There are different types of drilling fluid based on their composition and use. Cost, technical specifications and environmental impacts are to be considered in selection of the convenient drilling fluid. Drilling mud is classified into three main group; as waterbased, oil-based and air-based. Water-based fluids (WBFs) are the most widely used systems, and are considered less expensive than oil and air based systems. The waterbased drilling muds contain bentonite and barite as base solutions, as well as various additives such as carboxymethyl cellulose, polymers, etc. (Benchabane and Bekkour, 2006). Additives are used in order to meet the desired properties of the fluid when subjected to borehole conditions. In this study, fly ash is added into drilling mud and rheological and filtration properties of the prepared mud system is investigated. Fly ash is a waste byproduct generated from coal combustion. Coal fired thermal power plants produces huge amount of fly ash and generates world's largest quantity of solid wastes (Giere et al., 2003). The annual amount of fly ash in Turkey is expected to exceed 50 million tons by 2020 (Fatih and
Umit, 2001). In general, the chemical composition of fly ash is typically consist of silicon, calcium, aluminum, iron, magnesium, and sulfur oxides along with carbon and various trace elements. According to percentage of forementioned constituents of the ash, it is classified as $\mathrm{C}$ and F class ash based on ASTM C618 standart (ASTM, 1998). Physically, fly ash is generally grey in color, abrasive, mostly alkaline, and refractory in nature. There are many industries utilizing fly ash like cement production, building materials and concrete (Ahmaruzzaman, 2010). Fly ash is used in oilfield and petroleum industry for many reasons such as stabilization of drilling wastes to prevent pollution (Thompson, 1994), solidification processes (Conner and Hoeffner, 1998), as riser in deepwater drilling operations (Totten et al., 1998), and to keep circulation losses under control (Matho and Jain, 2013). Fly ash utilization is advantageous both economically as it is a easy accessible combustion waste and environmentally as it is eco-friendly and even improves the soil quality for the growth of plants (Pandey and Singh, 2010). Mahto and Jain, 2013; conducted an experimental work developing an water based drilling mud system by using fly ash to bridge across the pore throat in order to control filtration losses. They observed that the filtration properties were improved where finer particles promote bridging effect and decrease cake thickness and circulation losses. They also observed that the effect of fly ash on rheological properties of fly ash is negligible. Terakulsatit 2015, also mixed drilling mud with fly ash at 3, 5, $7 \% \mathrm{w} / \mathrm{v}$ concentrations at $30{ }^{\circ} \mathrm{C}, 60{ }^{\circ} \mathrm{C}$ and $90{ }^{\circ} \mathrm{C}$ and investigated the chemical and physical properties of the mud systems. The experiment show that drilling mud mixed with $3 \% \mathrm{w} / \mathrm{v}$ concentration of fly ash is a 
high potential additive for enhacement the rheological properties especially in increasing of apperant viscosity, yield point and gel strength. Ozkan et al., 2018; also investigated the effect of fly ash on drilling mud and observed that the results rheological properties such as plastic viscosity (PV) and apparent viscosity (AV) were slightly increasing up to $6 \%$ fly ash ratio in the drilling fluid after that the viscosities tend to decrease (Özkan et al., 2018).

In this experimental work, fly ash is added into drilling mud in different concentrations $(\% \mathrm{w} / \mathrm{v})$ and particle size and the changes in rheological and filtration properties are investigated based on API testing methods (API SPEC 13A).

\section{Material and Methods}

\subsection{Sample preperation}

Barite and bentonite are provided from Turkish Petroleum Corporation (TPAO). Fly ash is supplied from $600 \mathrm{MW}$ imported coal fired power plant in Turkey. Coal type burning in the boiler, method of combustion and fly ash capture mechanism characterizes the fly ash (Fatih and Umit, 2001). The bentonite and the barite powders were weighed and mixed with water and then the fly ash was added at different concentration $(1,2,3,4,5 \%)$.

\subsection{Analysis of the chemical and physical properties}

Fly ash is sieved with FRISTCH model vibrating sieve and $32 \mu \mathrm{m}, 63 \mu \mathrm{m}$ and $90 \mu \mathrm{m}$ subsieve samples are obtained. Blaine fineness of these samples are higher than $3000 \mathrm{~cm}^{2} / \mathrm{g}$. The elemental composition of the fly ash was determined using X-Ray Flourescence (XRF) of ARL OPTIMX model. The phase composition, functional groups and the morphological properties of the fly ash and the drilling fluids were analyzed by X-ray powder diffraction using Rigaku Miniflex 600 with $\mathrm{CuK \alpha}(40 \mathrm{kV}$, $15 \mathrm{~mA}, \lambda: 1.54050 \AA$ ) radiation and $\mathrm{LeO}$ EVO40 scanning electron microscope, respectively.

The physical properties of the drilling mud were determined based on API standard, including all filtration and rheological properties. Fann Viscometer was used to measure dial readings of the solutions. Rheological properties such as plastic viscosity, appearant viscosity, yield point and 10 min gel strenth were correlated according to the empirical formulas below;

$$
\begin{aligned}
& \mu_{\mathrm{p}}=\theta_{(600 \mathrm{rpm})}-\theta_{(300 \mathrm{rpm})} \\
& \gamma_{\mathrm{p}}=\theta_{(300 \mathrm{rpm})}-\mu_{\mathrm{p}} \quad \mu_{\mathrm{a}}=\frac{\theta(600 \mathrm{rpm})}{2} \\
& \mu_{\mathrm{p}}: \text { Plastic viscosity }(\mathrm{cp}) \\
& \gamma_{\mathrm{p}}: \text { Yield Point }\left(\mathrm{lb}_{\mathrm{f}} / 100 \mathrm{ft}^{2}\right) \\
& \mu_{\mathrm{a}}: \text { Appearent viscosity }(\mathrm{cp})
\end{aligned}
$$

API fluid loss test is used to measure the filtration properties of the prepared systems at ambient temperature and 100 psi pressure. Density of the mud was also measured using mud balance; consist of base and a balance arm with a cup for counterweight.

\subsection{Experimental work}

The powdered form of bentonite and barite are weighed. Then a water based drilling mud is prepared using $500 \mathrm{~mL}$ water, $31,25 \mathrm{~g}$ of bentonite, $14,25 \mathrm{~g}$ of barite and all this suspension is well mixed for 20 minutes with a mixer. Fly ash with $32 \mu \mathrm{m}, 63 \mu \mathrm{m}$ and 90 $\mu \mathrm{m}$ subsieve samples and concentrations of $1,2,3,4,5 \%$ by weight per volume is added 
slowly during mixing. After complete 16 hours prior to rheological and filtration mixing, prepared drilling muds are aged for tests.

Table 1. Composition of prepared drilling mud systems for each $32 \mu \mathrm{m}, 63 \mu \mathrm{m}$ and $90 \mu \mathrm{m}$ particle sizes

\begin{tabular}{lcccc}
\hline Composition & Water $(\mathbf{m l})$ & Bentonite $(\mathbf{g})$ & Barite $(\mathbf{g})$ & Fly Ash $(\mathbf{g})$ \\
\hline Spud & 500 & 31,25 & 14,25 & - \\
\hline Mud + 1\% FA & 500 & 31,25 & 14,25 & 5,45 \\
\hline Mud + 2\% FA & 500 & 31,25 & 14,25 & 10,91 \\
\hline Mud + 3\% FA & 500 & 31,25 & 14,25 & 16,36 \\
\hline Mud + 4\% FA & 500 & 31,25 & 14,25 & 21,82 \\
\hline Mud + 5\% FA & 500 & 31,25 & 14,25 & 27,28 \\
*FA: & & Fly & & Ash
\end{tabular}

\section{Resarch Findings}

\subsection{Characterization of fly ash and} drilling fluids

Chemical composition of fly ash depends mostly on coal being burned. Coals are classified according to its calorific values and four types (ranks) of coal are anthracite, bituminous,sub-bituminous, and lignite.

Herein this study bituminous coal fly ash is used. The elemental analysis of the fly ash determined by X-Ray Flouresence is given in Table 2. It was seen that the main composition of the fly ash consisted of silica and alumina. According to ASTM C 618-08a (Pandey and Singh, 2010).

Table 2. Composition of fly ash

\begin{tabular}{cc}
\hline Composition & $(\mathbf{w} \%)$ \\
\hline $\mathrm{SiO}_{2}$ & 56 \\
\hline $\mathrm{Al}_{2} \mathrm{O}_{3}$ & 21.5 \\
\hline $\mathrm{Fe}_{2} \mathrm{O}_{3}$ & 6.5 \\
\hline $\mathrm{CaO}$ & 4.1 \\
\hline $\mathrm{MgO}$ & 1.4 \\
\hline $\mathrm{Na}_{2} \mathrm{O}$ & 3 \\
\hline $\mathrm{K}_{2} \mathrm{O}$ & 1.8 \\
\hline $\mathrm{TiO}_{2}$ & 0.8 \\
\hline
\end{tabular}

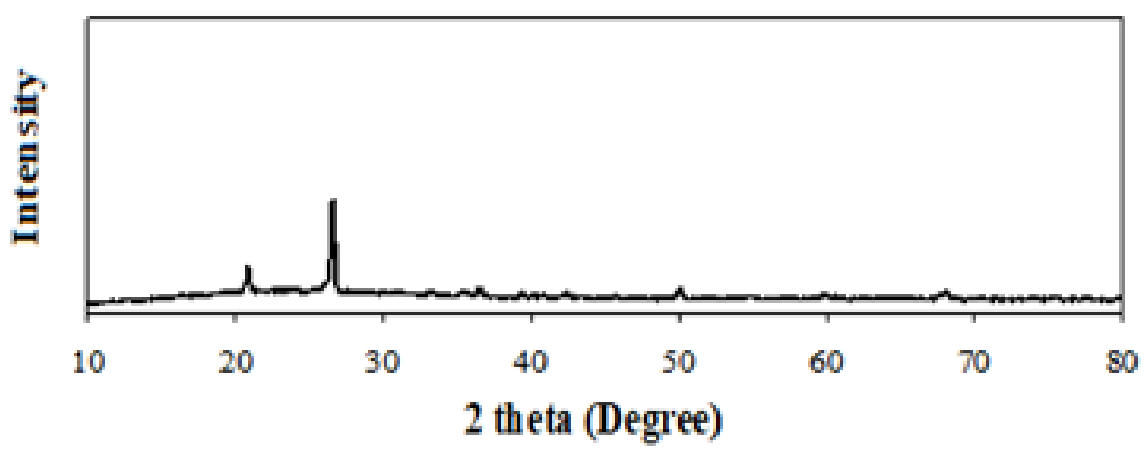

Fig. 1. The XRD patterns of the fly ash

The XRD results (Fig. 1) belonging to the fly ash showed that the main structure was quartz and the drilling fluids indicated that the quartz and bentonite structure. Morphological analysis of the fly ash and the drilling fluids indicated that fly ash particles were spherical and amorphous in shape (Fig. 2). In drilling fluids, the Na-bentonite structure was identified and the spherical fly ash particles were also seen in the structure. 


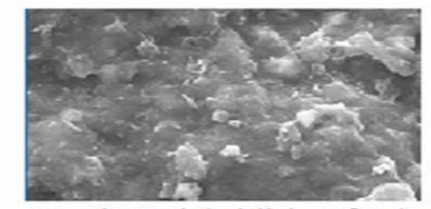

Spud Mud (addition free)

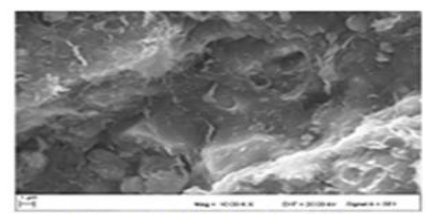

Fly ash $32 \mu \mathrm{m}(1 \%)$

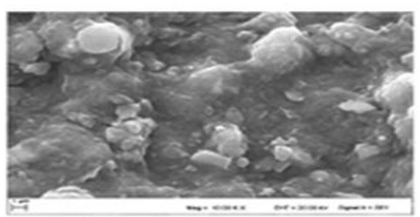

F1y ash $63 \mu \mathrm{m}(1 \%)$

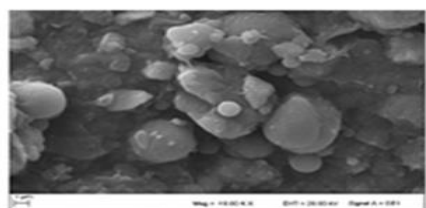

Fly ash $90 \mu \mathrm{m}(1 \%)$

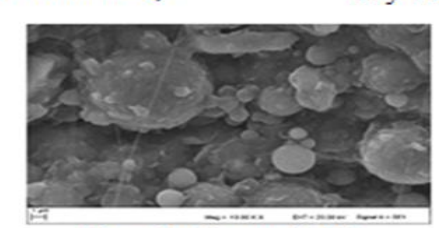

Fly ash $32 \mu \mathrm{m}(3 \%)$

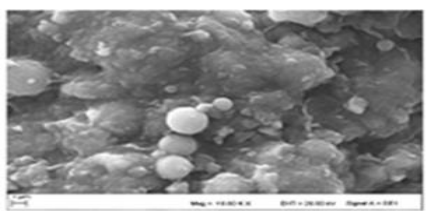

Fly ash $63 \mu \mathrm{m}(3 \%)$

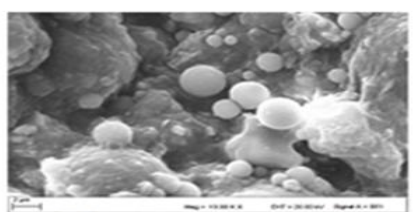

Fly ash $90 \mu \mathrm{m}(3 \%)$

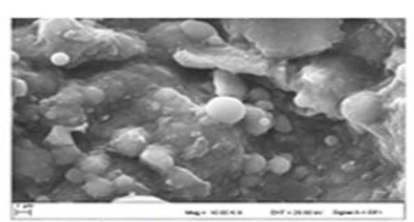

Fly ash $32 \mu \mathrm{m}(5 \%)$

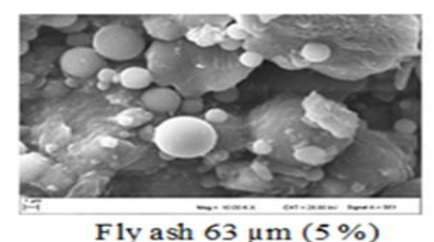

F1y ash $63 \mu \mathrm{m}(5 \%)$

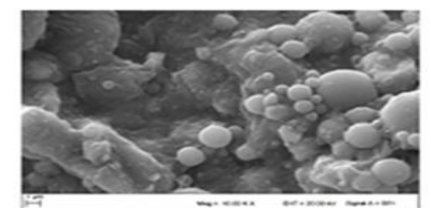

F1y ash $90 \mu \mathrm{m}(5 \%)$

Fig. 2. SEM images of spud mud, fly ash and fly ash addition with diffferent particle size and concentration

3.2. Changes in the physical and sizes were mixed with the drilling fluid rheological properties of the prepared separately and their effects on water-base mud systems with fly ash addition

In the present study, 1, 2, 3, 4, $5 \%(\mathrm{w} / \mathrm{v})$ of fly ash ratio as additives with different drilling muds were investigated. Density of the prepared mud systems is increased with fly ash addition as seen in Fig. 3 . particle

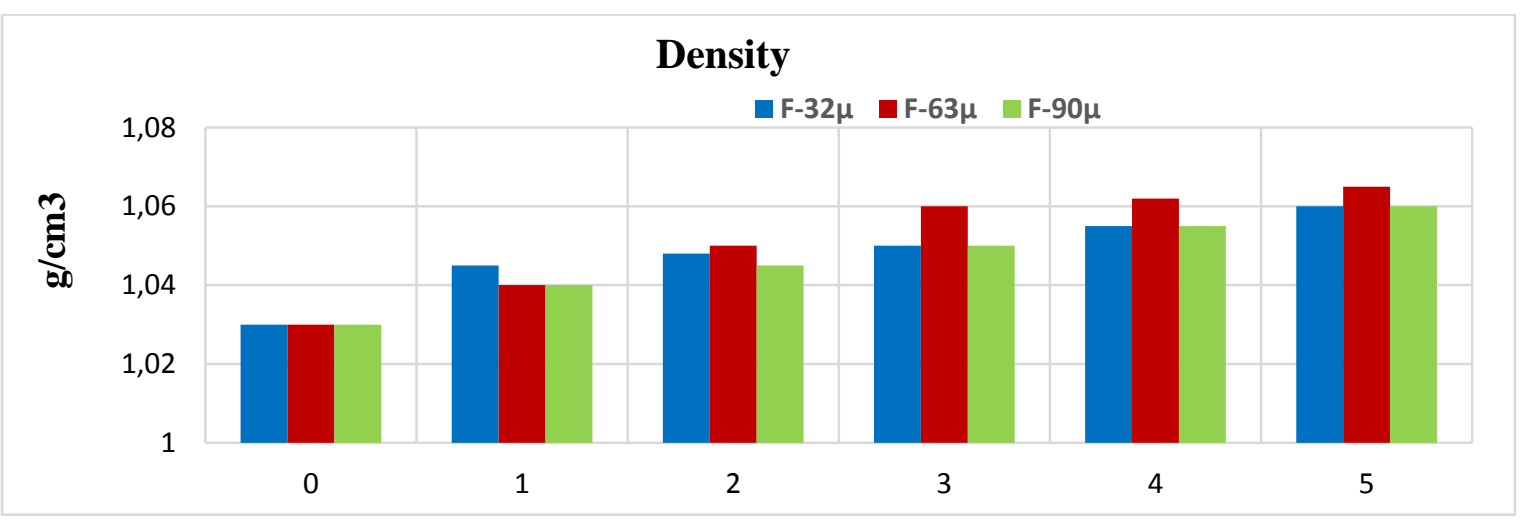

Fig. 3. Density of the prepared mud systems

Hydrostatic pressure (PH) of the drilling mud which is important for the control of formation pressure is adjusted by the density of the mud. Hydrostatic pressure of the drilling mud is a function of borehole depth and mud density. From the figure above, density is increasing with particle size of the ash as well as concentration. 
The findings of the experimental study were compared with API requirements which are shown in Table 3 below.
Effect of fly ash on plastic viscosity, apparent viscosity and yield point of the prepared mud systems are shown in the figures given

Table 3. API Standart Specifications (16)

\begin{tabular}{cc}
\hline \multicolumn{2}{c}{ Rheological Properties } \\
\hline$\Theta 600$ & 30 Minimum \\
\hline$\Theta 300$ & 23 Minimum \\
\hline Plastic Viscosity $(\mathrm{cP})$ & $6-8$ Minimum \\
\hline ApparentViscosity $(\mathrm{cP})$ & 12-15 Minimum \\
\hline Yield Point $(\mathrm{lb} / 100 \mathrm{ft} 2)$ & 3 *PV or 50 Maximum \\
\hline Filtrate Loss $(\mathrm{mL})$ & 30
\end{tabular}

\section{Rheological Proporties of F-32 $\boldsymbol{\mu}$ added WBDF}

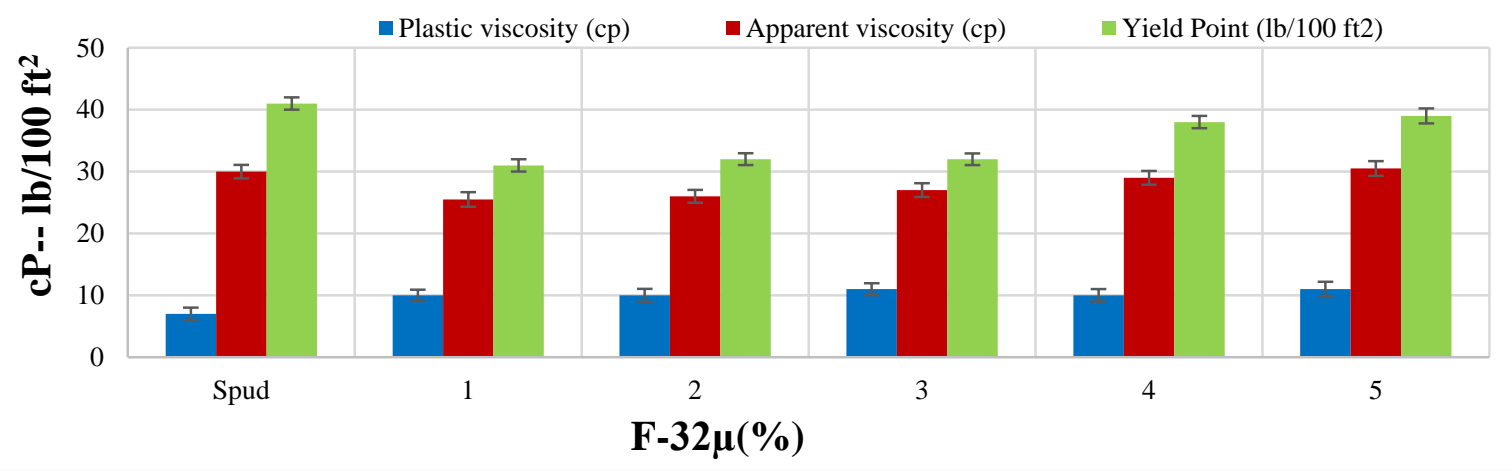

Fig. 4. PV, AV and YP of the $32 \mu$ FA added mud system

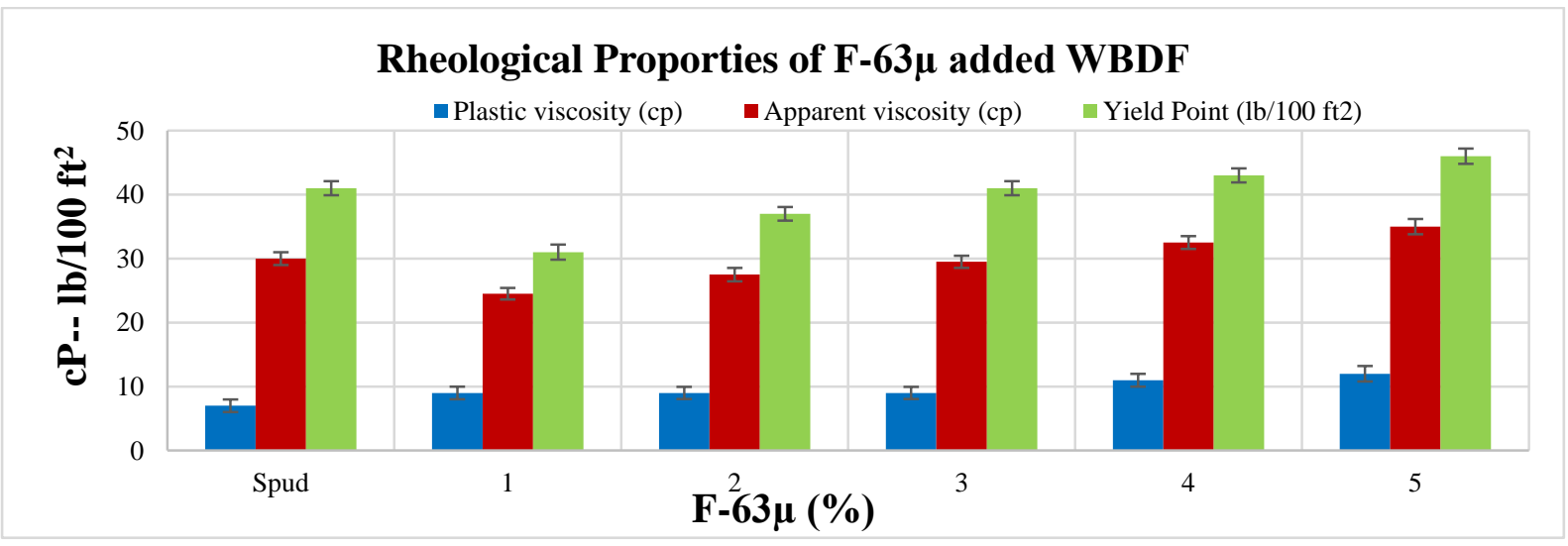

Fig. 5. PV, AV and YP of the $63 \mu$ FA added mud system 


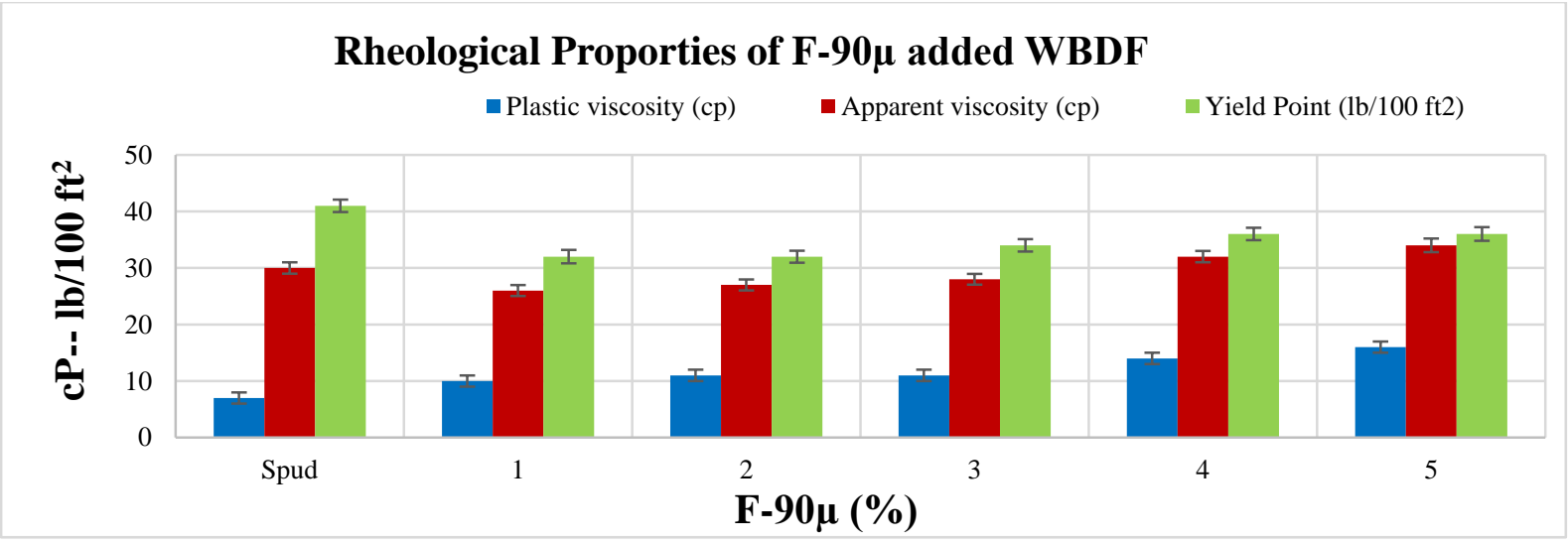

Fig. 6. PV, AV and YP of the $90 \mu \mathrm{m}$ FA added mud system

Viscocity is highly effected from the base liquid and the amount of additives expecially of solids. For example barite is a heavy material and the fluid including higher amount of barite performs higher viscosity. Typically, big holes require thicker fluids, on the other hand smaller diameter holes require thinner fluids. As seen from the figures above, plastic viscosity and apparent viscosities of the prepared mud systems are increasing with increasing fly ash concentration. According to API standart yield point should not pass the value of 50 for the quality of drilling operation. Fig. 4 shows that PV, AV and yield point of the 32 $\mu \mathrm{m}$ fly ash addition are not effected up to 3 $\%$ concentration, after then viscosities are slightly increasing. For $63 \mu \mathrm{m}$ fly ash addition $\mathrm{PV}$ is effected after $3 \%$ concentration while the increase of $\mathrm{AV}$ and yield point is initiated from $1 \%$ concentration (Fig. 5). For $90 \mu \mathrm{m}$ fly ash addition, behaviour of the viscosities and yield point change is similar to $63 \mu \mathrm{m}$ fly ash addition as seen in the
Fig. 6. For all particle sizes, it was seen that YP was improved with the increase in fly ash addition, which greatly affects carriying capacity and hole cleaning (Bourgeyne et al., 1986). The ratio of YP to PV is a critical parameter for stable and optimal mud performance (Chilingarian et al., 1986).

Gel strengths is the shear stress needed to initiate flow after the drilling fluid has been static for some time. Gel strength determines the pressure required to "break circulation" and the ease of releasing entrained gas or air. Measurement is done using the same rotational viscometer like viscosity measurements. Gel strength measurement is made with viscometer according to readings after 10 minutes and 10 seconds stirring of the mud. Effect of fly ash on gel strength of the prepared mud systems are shown in the figures

below.

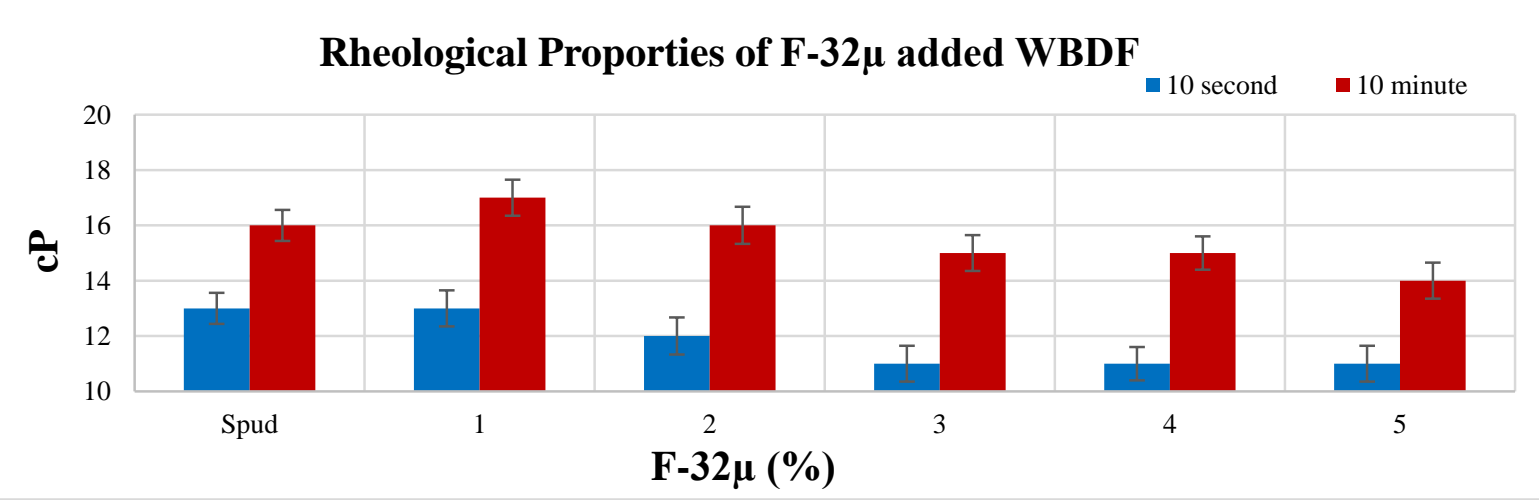

Fig. 7. Gel strength of the $32 \mu \mathrm{m}$ FA added Mud System 


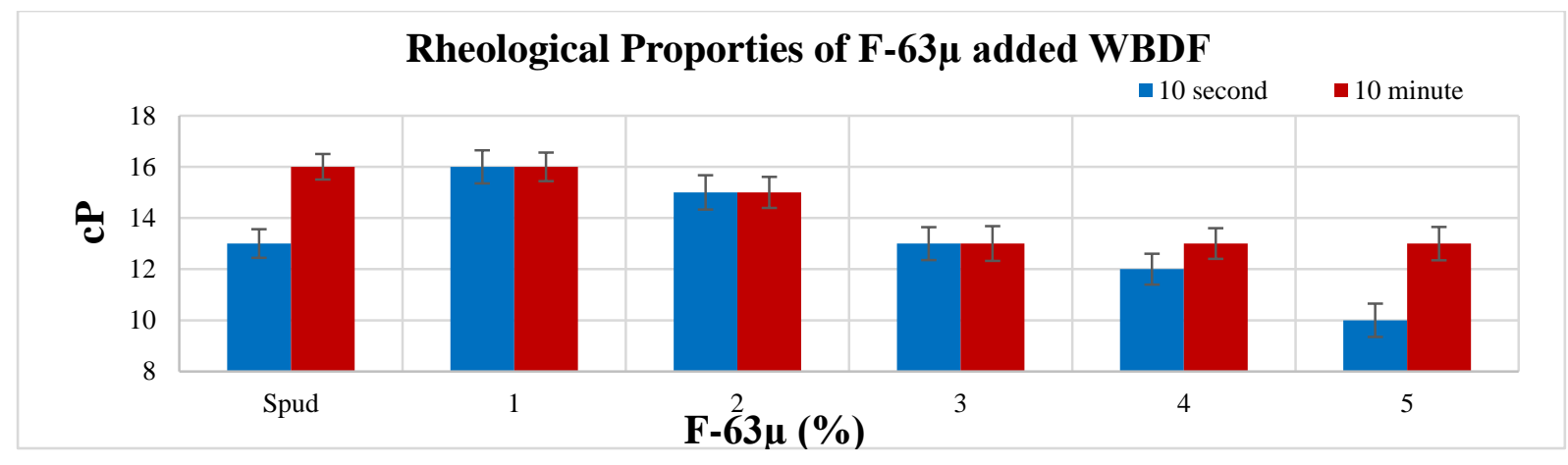

Fig. 8. Gel strength of the $63 \mu \mathrm{m}$ FA added Mud System

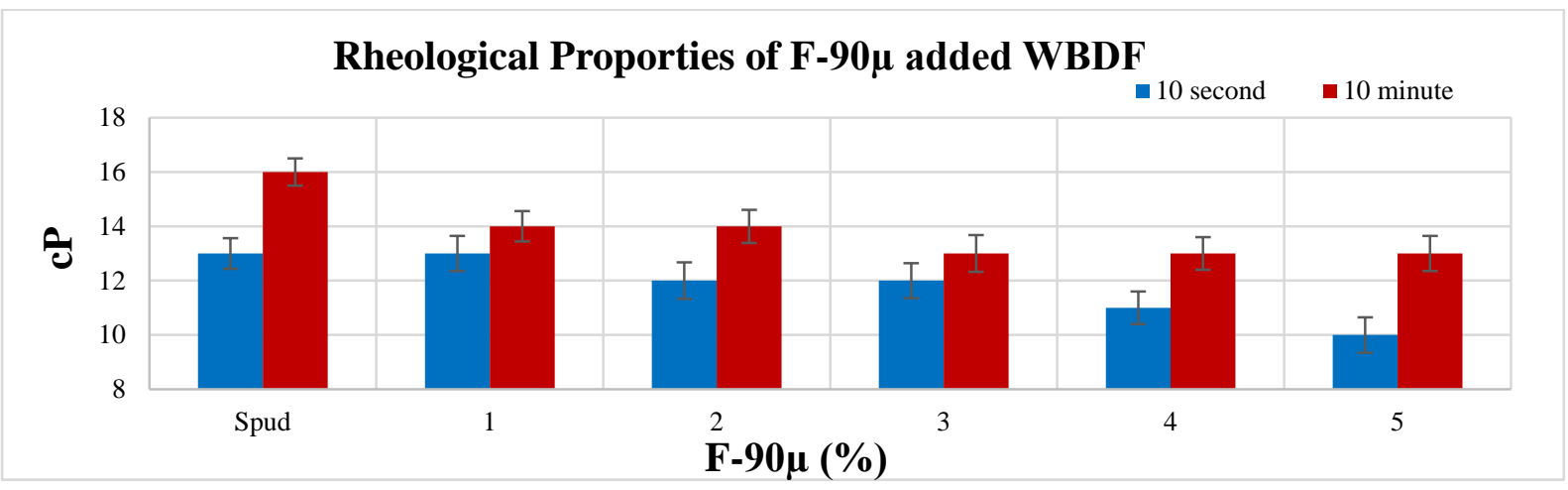

Fig. 9. Gel strength of the $90 \mu \mathrm{m}$ FA added Mud System

Gel strength of the prepared mud systems meet the API requirements. It is observed that for all particle sizes, 10 seconds and 10 minutes gel strenghs are decreased with increasing fly ash concentration. For $63 \mu \mathrm{m}$ and $90 \mu \mathrm{m}$ fly ash additions 10 minutes gel strength of the systems are constant after 3\% fly ash concentration.
The filtration loss of the drilling fluid decreased with increasing the fly ash concentration. Since, the fly ash consist of ultra-fine particles, these particles penetrate into holes and decrease permeability of the drilling fluid into formations. Filtration losses of the prepared mud systems are shown in figure 10 below.

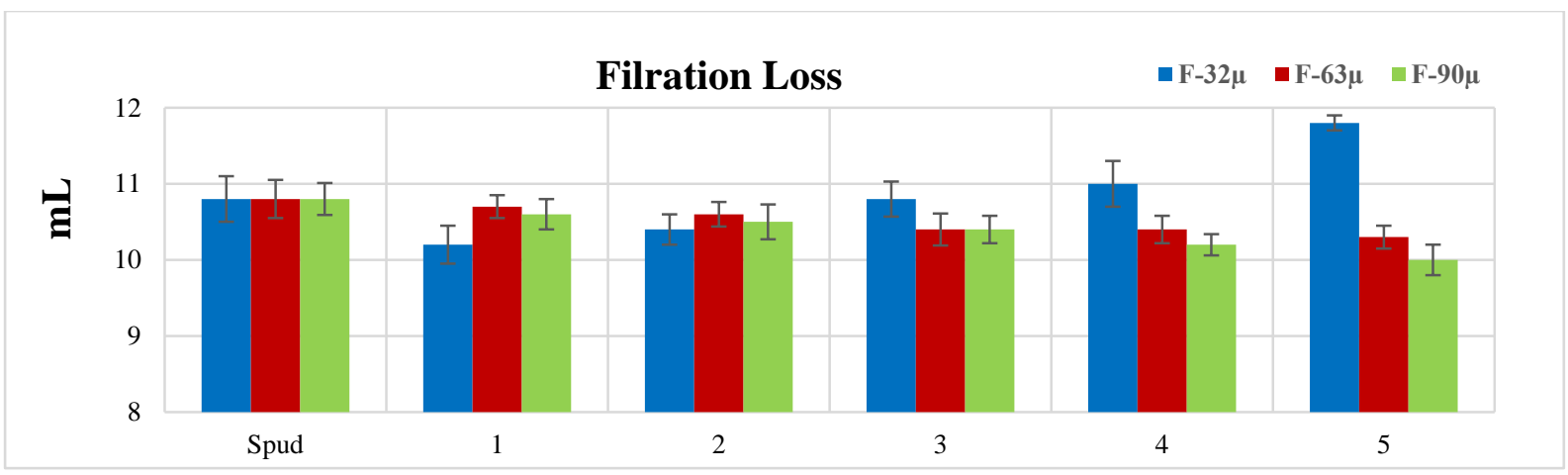

Fig. 10. Filtration Loss of the FA added Mud Systems 
Fly ash addition is decreased the filtration losses which is a highly desirable property and leads to reduce drilling cost. $32 \mu \mathrm{m}$ fly ash addition most contributed to decrease filtration loss.

\section{Results}

In this experimental study; Changes in rheological and filtration properties were investigated by adding fly ash to the drilling mud at different concentrations (w/v \%) and particle size. The results of the study are presented in Table 4.

Table 4. . Analysis Results of Fly Ash Additive Water Based Drilling Mud

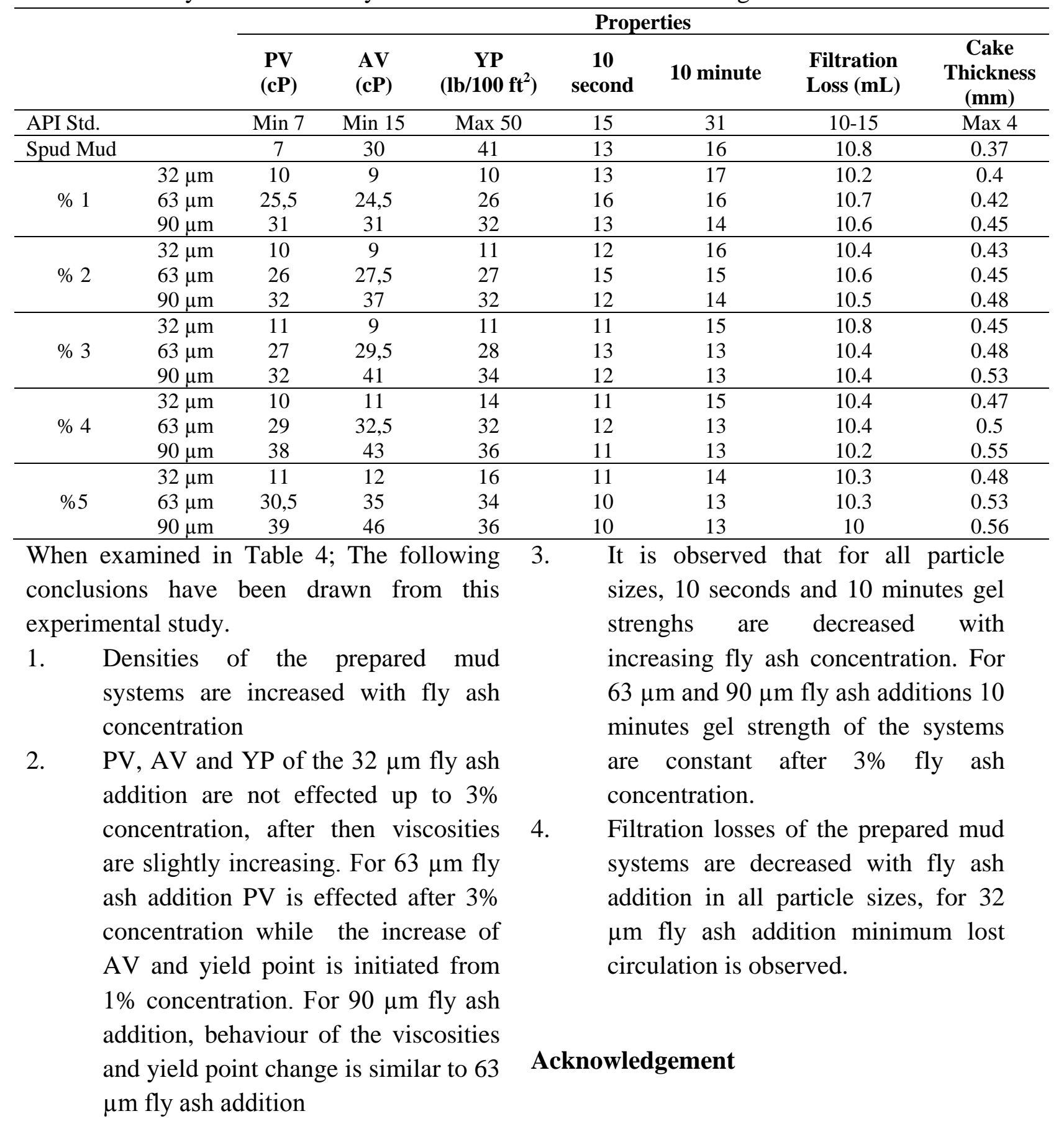


We would like to thank Prof. Dr. Tolga DEPCI for his contributions in making and interpreting XRD and SEM analyzes.

\section{References}

Abdo, J., \& Haneef, M. (2012). "Nanoenhanced drilling fluids: pioneering approach to overcome uncompromising drilling problems." Journal of Energy Resources Technology, 134(1).

Ahmaruzzaman, M. (2010). "A review on the utilization of fly ash." Progress in Energy and Combustion Science, 36(3), 327-363.

API SPEC 13A, (2010). Specification for Drilling Fluids - Specifications and Testing, 18th ed, Purchasing Guidelines Handbook, American Petroleum Institute (API).

ASTM C, (1998). Standard specification for coal fly ash and raw or calcined natural pozzolan for use as a mineral admixture in concrete. 1998 Annual Book of ASTM Standards, 4, pp-293.

Benchabane, A., \& Bekkour, K. (2006). "Effects of anionic additives on the rheological behavior of aqueous calcium montmorillonite suspensions." Rheologica acta, 45(4), 425-434.

Bourgoyne Jr, A. T., Millheim, K. K., Chenevert, M. E., \& Young Jr, F. S. (1986). Applied drilling engineering. Volume 2.

Caenn, R., Darley, H. C., \& Gray, G. R. (2011). "Composition and properties of drilling and completion fluids." Gulf professional publishing.

Chilingarian, G. V., Alp, E., Caenn, R., AlSalem, M., Uslu, S., Gonzales, S., ... \& Yen, T. F. (1986). "Drilling fluid evaluation using yield point-plastic viscosity correlation." Energy sources, 8(2-3), 233-244.

Conner, J. R., \& Hoeffner, S. L. (1998). “The history of stabilization/solidification technology." Critical reviews in environmental science and technology, 28(4), 325-396.

Fatih, T., \& Umit, A. (2001, October). "Utilization of fly ash in manufacturing of building bricks. In International ash utilization symposium." Center for applied energy research, University of Kentucky Paper (Vol. 13).

Gieré, R., Carleton, L. E., \& Lumpkin, G. R. (2003). "Micro-and nanochemistry of fly ash from a coal-fired power plant." American Mineralogist, 88(11-12), 1853-1865.

Mahto, V. (2010). "Development of Optimum Water Based Oil Well Drilling Fluids: A Systematic Approach." LAP Lambert Academic Publishing.

Mahto, V., \& Jain, R. (2013). "Effect of fly ash on the rheological and filtration properties of water based drilling fluids." International Journal of Research in Engineering and Technology, 2(8), 50-156.

Ozkan, A., Turan, S. E., \& Kaplan, B. M. (2018). "Investigation of fly ash effect on rheological and filtration properties of drilling muds." Fresenius Environmental Bulletin, 27(12 A), 9189-9194.

Pandey, V. C., \& Singh, N. (2010). "Impact of fly ash incorporation in soil systems." Agriculture, ecosystems \& environment, 136(1-2), 16-27. 
Terakulsatit, B. (2015). "Physical and chemical properties of drilling mud by using fly ash as an additive." Global conference on engineering and applied sciences, Hong Kong.

Thompson, L. F. (1994, January). "Drilling fluids waste minimization and stabilization using polymer technology." In SPE Eastern Regional Meeting. Society of Petroleum Engineers.

Totten, P. L., King, B. L., \& Griffith, J. E. (1998). U.S. Patent No. 5,716,910. Washington, DC: U.S. Patent and Trademark Office. 